\title{
TINGKAT KETAHANAN KLON POTENSIAL UBI JALAR LOKAL ASAL NTT TERHADAP HAMA LANAS (CYLAS FORMICARIUS FAB.)
}

\author{
Yosep Seran Mau', Antonius SS Ndiwa ${ }^{1}$ \& I GB Adwita Arsa ${ }^{1,2}$ \\ ${ }^{1}$ Fakultas Pertanian, Universitas Nusa Cendana, Jl. Adisucipto Penfui, Kupang, NTT 85001. \\ Email: yosepmau@yahoo.com \\ ${ }^{2}$ Pusat Studi Umbi-umbian dan Kacang-kacangan, Lembaga Penelitian Undana
}

\begin{abstract}
Resistance level of potential sweetpotato clones from NTT to sweet potato weevil (Cylas formicarius Fab.) A laboratory experiment was carried out to evaluate the potential sweetpotato clones from NTT for the following objectives: 1) to determine resistance level of the clones to sweetpotato weevil (SPW), 2) to investitage the effect of genotype by tuber production site interaction on SPW-resistance level, 3) to identify SPW-resistant clones. Sweetpotato roots employed in the experiment were obtained from two production sites in the fields. The experiment was laid out in a Completely Randomized Design with a factorial treatment of two factors: sweetpotato genotype (10 clones) and root production sites (two sites). Experimental unit was replicated three times. Variables observed included percentage of SPW-injured root, severity of root injury, number of larva, pupae and imago, and root morphological characters. Quantitative data were subjected to analysis of variance while qualititave data were descriptively analyzed. Results of the study revealed significant interaction effect of genotype by tuber production site on severity of root injury and number of larva+pupae+imago. NBN-01 and NPL-02 produced the lowest $(4.50 \%)$ and the greatest $(67.03 \%)$ severity of root injury. NBN-01 was classified "resistant" and NPL-02 was "susceptible" while the remaining eight clones/check varieties were "moderately resistant" to SPW.
\end{abstract}

Key words: Resistance level, sweet potato, local clone, sweet potato weevil, Cylas formicarius

\begin{abstract}
ABSTRAK
Tingkat ketahanan klon potensial ubi jalar Lokal asal NTT terhadap hama lanas (Cylas formicarius Fab.) Suatu percobaan laboratorium dilakukan untuk mengevaluasi sejumlah klon potensial ubi jalar lokal NTT dengan tujuan: 1) mengetahui tingkat ketahanan klon-klon tersebut terhadap hama lanas, 2) mengkaji pengaruh interaksi genotip dan lokasi produksi umbi terhadap ketahanan, 3) mengidentifikasi klon-klon yang tahan terhadap hama lanas. Umbi yang digunakan diperoleh dari dua lokasi penanaman di lapangan. Percobaan diatur dalam rancangan lingkungan Acak Lengkap dengan rancangan perlakuan faktorial. Perlakuan yang diuji terdiri dari dua faktor; genotipe ubi jalar (10 klon) dan lokasi produksi umbi (dua lokasi), masing-masing tiga ulangan. Peubah yang diamati meliputi persentase umbi terserang, severitas (tingkat keparahan) umbi terserang, jumlah larva, pupa dan imago, serta karakter morfologis umbi. Data kuantitatif dianalisis dengan sidik ragam, sedangkan data kualitatif dianalisis secara deskriptif. Hasil sidik ragam menunjukkan bahwa interaksi gentotip dan lokasi produksi umbi berpengaruh nyata terhadap severitas umbi terserang dan jumlah larva+pupa+imago. Klon lokal NBN-01 dan NPL-02 menunjukkan severitas umbi terserang terendah dan tertinggi, masing-masing 4,50\% dan 67,03\%. Klon NBN-01 tergolong "tahan" dan klon NPL-02 tergolong "peka", sedangkan delapan klon lainnya tergolong "agak tahan" terhadap hama lanas.
\end{abstract}

Kata kunci: tingkat ketahanan, ubi jalar, klon lokal, hama lanas, Cylas formicarius

\section{PENDAHULUAN}

Hama lanas [Cylas formicarius (Fab.)] merupakan salah satu hama utama tanaman ubi jalar yang dapat merusak umbi di pertanaman maupun di penyimpanan (Mao et al., 2004; Zuraida et al., 2004; Jansson \& Bryan, 1987). Serangan hama ini dapat menimbulkan kehilangan hasil antara $10-80 \%$ tergantung pada lokasi dan musim. Selain menyebabkan kehilangan hasil, serangan hama ini sangat berpengaruh terhadap kualitas hasil umbi karena umbi yang terserang akan terasa pahit sehingga tidak disukai oleh konsumen dan menurunkan nilai jual hasil umbi. Selain itu, serangan hama lanas dapat memperpendek daya simpan dan mengurangi daya tumbuh ubi jalar.

Banyak upaya telah dilakukan untuk pengendalian hama lanas namun kurang efektif karena kerusakan terbesar biasanya disebabkan oleh stadia larva yang tinggal di dalam umbi yang terletak di dalam tanah sehingga sulit untuk dikendalikan. Upaya yang dianggap 
paling efektif adalah penggunaan varietas tahan, namun sejauh ini varietas tahan yang tersedia masih sangat terbatas.

Tingkat ketahanan terhadap hama lanas pada kebanyakan varietas unggul komersial yang tersedia saat ini masih berkisar antara agak tahan hingga agak peka (Rukmana, 1997; Cahyono \& Juanda, 2000). Kesulitan memperoleh varietas unggul tahan hama lanas antara lain karena kurang tersedianya plasma nutfah sebagai sumber genetik ketahanan dimaksud. Salah satu upaya yang bisa dilakukan untuk mengatasi keadaan ini adalah menghasilkan varietas unggul melalui seleksi plasma nutfah lokal yang tersedia, yang selain memiliki keunggulan dalam produksi, daya adaptasi, dan kandungan gizi, juga memiliki keunggulan dalam ketahanan terhadap hama lanas.

Beberapa kajian telah dilakukan terhadap klon lokal ubi jalar asal NTT, baik mengenai koleksi dan identifikasi (Ndiwa et al., 2007), tingkat ketahanan terhadap cekaman kekeringan (Mau et al., 2008) serta daya hasil dan daya adaptasi (Mau et al., 2009). Berdasarkan hasil kajian tersebut diketahui bahwa sejumlah klon memiliki daya hasil tinggi dan stabil, tahan terhadap cekaman kekeringan, dan memiliki kandungan gizi tinggi (protein dan beta karoten). Klon-klon tersebut dianggap potensial untuk dikembangkan dan diusulkan sebagai calon varietas unggul spesifik lokasi NTT. Namun, informasi mengenai sifat ketahanan terhadap salah satu hama utama ubi jalar, hama lanas, belum tersedia. Oleh karena itu, penelitian ini dilakukan dengan tujuan menyelidiki: 1). tingkat ketahanan klon-klon ubi jalar yang diuji terhadap hama lanas, 2). pengaruh interaksi jenis klon dan lokasi produksi umbi terhadap tingkat ketahanan, dan 3). Klon-klon yang memiliki ketahanan yang baik terhadap hama lanas.

\section{METODE PENELITIAN}

Tempat dan Waktu. Percobaan lapangan dilakukan di dua lokasi untuk memperoleh umbi ubi jalar, yang kemudian digunakan untuk evaluasi ketahanan terhadap hama lanas di laboratorium. Percobaan lapangan dilakukan di lahan kebun petani di Desa Kesetnana, Kabupaten TTS, Timor Barat $(800 \mathrm{~m}$ dpl, jenis tanah Alvisol, tekstur liat berpasir, N: 0,12\%; P: 116,55 ppm dan K: 0,5 me/100) dan di Desa Detubapa, Kabupaten Ende, Flores (615 m dpl, jenis tanah Inseptisol, lempung berpasir, N: 0,25\%; P: 141,80 ppm dan K: 1,36 me/100). Percobaan laboratorium evaluasi ketahanan dilaksanakan di Laboratorium Hama Tumbuhan, Fakultas Pertanian Universitas Nusa Cendana, Kupang, NTT.
Penelitian ini berlangsung dari bulan Juni hingga November 2010.

Metode yang digunakan untuk evaluasi ketahanan adalah metode eksperimen, yang dirancang dalam Rancangan Acak Lengkap (RAL) dengan pola perlakuan faktorial, terdiri dari faktor genotip ubi jalar (10 klon) dan lokasi produksi umbi (dua lokasi), masingmasing terdiri dari tiga ulangan. Seluruhnya terdapat 60 unit percobaan.

Prosedur Penelitian. Umbi untuk evaluasi ketahanan di laboratorium diperoleh dari tanaman ubi jalar yang ditanam di lapangan. Lahan penanaman ubi jalar di lapangan, masing-masing dibagi dalam tiga blok, setiap blok sebagai ulangan. Penanaman dilakukan pada petak percobaan berukuran $3 \mathrm{~m} \times 1 \mathrm{~m}$ dengan sistem one-row plot, masing-masing ditanami 5 tanaman. Benih yang digunakan berasal dari bahan stek ujung sepanjang 2530 , ditanam dengan cara membenamkannya sedalam 6-8 cm, 1/3 bagian (pangkal) stek dimasukkan dalam lubang serta $2 / 3$ bagian (ujung) stek dibiarkan di atas permukaan tanah. Pemupukan dilakukan pada saat tanam dengan dosis $45 \mathrm{~g}$ Urea, $30 \mathrm{~g}$ TSP dan $30 \mathrm{~g} \mathrm{KCl}$ per petak, setara dengan $150 \mathrm{~kg}$ Urea, $100 \mathrm{~kg}$ TSP dan $100 \mathrm{~kg} \mathrm{KCl}$ per hektar. Tindakan pemeliharaan meliputi penyiraman, penyulaman dan penyiangan gulma. Pemanenan dilakukan pada saat tanaman berumur sekitar 4 bulan setelah tanam.

Percobaan di laboratorium dilakukan dengan cara infestasi hama lanas secara buatan terhadap umbi yang diperoleh dari dua lokasi penanaman di lapangan. Pelaksanaan percobaan di laboratorium mengikuti prosedur oleh Supriyatin \& Rahayuningsih (1994) dan Zuraida et al. (2005). Sebanyak 3 umbi berukuran sedang (masing-masing berkisar 200-300 gram) diambil dari tiap-tiap klon dan ditempatkan ke dalam kotak plastik (volume 3,5 L) dengan tutup dari kain kassa. Masingmasing klon terdiri dari tiga ulangan.

Masing-masing kotak plastik diinfestasi dengan lima pasang (jantan+betina) hama lanas dewasa (imago) berumur sekitar 1 bulan dan ditempatkan pada ruangan tanpa cahaya. Lima hari setelah infestasi, pasanganpasangan hama lanas tersebut dikeluarkan dari kotak plastik, kemudian kotak plastik berisi umbi dikembalikan ke tempat semula selama 30 hari. Setelah itu, umbi dikeluarkan dari kotak percobaan dan dilakukan pengamatan terhadap peubah-peubah penelitian.

Pengamatan. Tiga peubah utama yang diamati meliputi persentase jumlah umbi terserang, severitas (tingkat keparahan) umbi terserang, dan jumlah populasi larva, 
pupa, dan imago $C$. formicarius. Peubah penunjang yang diamati adalah karakteristik morfologis umbi. Persentase jumlah umbi terserang diamati terlebih dahulu dengan memisahkan umbi terserang dari umbi sehat. Kemudian, persentase jumlah umbi terserang dihitung dengan rumus: $\mathrm{I}=(\mathrm{a} / \mathrm{b}) \times 100 \%$, dengan $\mathrm{I}$ adalah persentase umbi terserang, a adalah jumlah umbi yang terserang hama lanas, dan $\mathrm{b}$ adalah jumlah keseluruhan umbi (umbi terserang dan umbi sehat) pada masingmasing unit sampel.

Pengamatan severitas (tingkat keparahan) umbi terserang dilakukan dengan cara membelah umbi secara hati-hati pada luasan permukaan terbesar, kemudian secara visual memperkirakan persentase luasan permukaan belahan umbi yang rusak akibat serangan hama lanas, dengan kisaran 0\% (tidak rusak sama sekali) hingga $100 \%$ (seluruh luasan permukaan belahan umbi rusak) (Zuraida et al., 2005). Untuk menentukan tingkat ketahanan, mula-mula severitas umbi terserang diberi skor sesuai prosedur menurut Amalin (1994) sebagai berikut; severitas umbi terserang $<1 \%$ diberi skor 1,1 $25 \%$ diberi skor 2, 26-50\% diberi skor 3, 51-75\% diberi skor 4, dan 76-100\% diberi skor 5. Selanjutnya, tingkat ketahanan klon ubi jalar terhadap hama lanas ditentukan berdasarkan rata-rata skor severitas umbi terserang dengan kriteria sebagai berikut: "tahan" $(\mathrm{T})$ dengan ratarata skor 1,0-<1,5; "agak tahan" (AT) dengan skor 1,5$<2,5$; "agak peka" (AP) dengan skor 2,5-<3,5, dan "peka" (P) dengan skor 3,5-5,0.

Jumlah populasi larva, pupa, dan imago dihitung dengan cara membelah umbi secara hati-hati kemudian larva, pupa dan imago yang terdapat dalam umbi dihitung. Pengamatan dilakukan terhadap semua umbi sampel pada tiap-tiap kotak percobaan kemudian dirata-ratakan. Karakter morfologis umbi yang diamati meliputi warna daging dan warna kulit umbi, ketebalan kulit umbi, dan produksi getah.

Analisis Data. Data persentase jumlah umbi terserang, severitas umbi terserang, dan jumlah populasi larva+pupa+imago dianalisis dengan sidik ragam, kemudian diikuti dengan uji lanjut DMRT (taraf 0,05) untuk melihat perbedaan antarrerata perlakuan. Data skor ketahanan yang dikonversi dari data severitas umbi terserang, dianalisis secara kualitatif deskriptif untuk mengelompokkan tingkat ketahanan klon-klon ubi jalar yang diuji. Analisis korelasi dilakukan untuk melihat hubungan antara severitas (tingkat keparahan) umbi terserang dengan jumlah populasi larva+pupa+imago $C$. formicarius. Data karakter morfologis umbi dianalisis secara deskriptif untuk melihat keterkaitannya dengan tingkat ketahanan.

\section{HASIL DAN PEMBAHASAN}

\section{Persentase Umbi Terserang dan Severitas Umbi}

Terserang. Hasil analisis ragam (Tabel 1) menunjukkan bahwa interaksi antara genotip dan lokasi produksi umbi berpengaruh tidak nyata $(\mathrm{P}>0,05)$ terhadap persentase jumlah umbi terserang. Hasil ini mengindikasikan tidak adanya perbedaan penampilan tiap-tiap klon yang diuji berdasarkan lokasi produksi umbi. Secara faktor tunggal, jenis klon berpengaruh sangat nyata $(\mathrm{P}<0,01)$ terhadap persentase jumlah umbi terserang, sedangkan lokasi produksi umbi tidak berpengaruh terhadap peubah ini. Hal ini menunjukkan adanya perbedaan penampilan klonklon yang diuji pada masing-masing lokasi produksi umbi, namun persentase umbi terserang tiap-tiap klon pada kedua lokasi tidak berbeda secara statistik. Sebagai perbandingan, hasil penelitian Mao et al. (2001) menunjukkan bahwa baik lokasi produksi umbi maupun genotip ubi jalar berpengaruh secara signifikan terhadap jumlah luka pada permukaan umbi. Pengamatan pada umbi asal TTS (Tabel 2) menunjukkan bahwa rerata persentase umbi terendah diperoleh pada klon lokal NBN-01 (24,08\%), sedangkan persentase tertinggi pada klon lokal NPL-02 (88,28\%). Pada umbi asal lokasi Ende, kedua klon yang sama menunjukkan persentase umbi terserang terendah dan tertinggi, berturut-turut sebesar 30,58\% (NBN-01) dan 77,68\% (NPL-02).

Tidak seperti halnya persentase jumlah umbi terserang, pengaruh interaksi genotip dan lokasi produksi umbi sangat nyata $(\mathrm{P}<0,01)$ terhadap severitas umbi terserang (Tabel 1). Hal ini berarti severitas umbi terserang dipengaruhi oleh latar belakang genetik klonklon ubi jalar yang diuji, dan perbedaan ekspresi genetik ini dipengaruhi kondisi lingkungan di mana umbi klonklon ubi jalar tersebut diperoleh. Severitas umbi terserang yang ditimbulkan oleh hama lanas berkisar antara 3,83\% hingga $67,89 \%$ (Tabel 2). Severitas umbi terserang tidak terpola secara jelas, namun terlihat bahwa severitas umbi terserang tertinggi diperoleh pada klon lokal NPL02 baik untuk umbi dari lokasi TTS $(66,16 \%)$ maupun Ende $(67,89 \%)$, sedangkan severitas umbi terserang terendah diperoleh pada klon lokal NBN-01 sebesar $3,83 \%$ dan $5,17 \%$; berturut-turut untuk umbi dari lokasi TTS dan Ende. Berdasarkan lokasi produksi umbi, severitas umbi terserang pada klon ON-07, ORM-02, SEO-01, dan P.Solossa yang diperoleh dari Ende nyata lebih tinggi dari umbi asal lokasi TTS. Hal ini 
Tabel 1: Hasil analsisi sidik ragam persentase jumlah umbi terserang, severitas umbi terserang, sk or ketahanan, dan jumlah larva+pupa+imago pada klon-klon ubi jalar yang diuji.

\begin{tabular}{|c|c|c|c|c|c|c|c|c|c|c|}
\hline \multirow{2}{*}{ SK } & \multirow{2}{*}{$\mathrm{db}$} & \multicolumn{3}{|c|}{$\mathrm{KT}$} & \multicolumn{3}{|c|}{$F_{\text {hitung }}$} & \multicolumn{3}{|c|}{$F_{\text {(Prob.) }}$} \\
\hline & & PJUT & SUT & JLPI & PJUT & SUT & JLPI & PJUT & SUT & JLPI \\
\hline Lokasi (L) & 1 & 43,86 & 3583,16 & 0,74 & $0,18^{\mathrm{tn}}$ & $7,40^{*}$ & $1,87^{\mathrm{tn}}$ & 0,685 & 0,024 & 0,205 \\
\hline Klon (K) & 9 & 1546,86 & 1825,14 & 2,38 & $6,27^{* *}$ & $3,77^{*}$ & $6,01^{* *}$ & 0,006 & 0,031 & 0,007 \\
\hline $\mathrm{K}^{*} \mathrm{~L}$ & 9 & 246,56 & 484,30 & 0,39 & $0,71^{\mathrm{tn}}$ & $3,84^{* *}$ & $2,90^{* *}$ & 0,701 & 0,002 & 0,009 \\
\hline Galat & 40 & 346,18 & 126,11 & 0,14 & & & & & & \\
\hline Total & 59 & & & & & & & & & \\
\hline
\end{tabular}

$\mathrm{SK}=$ Sumber Keragaman, $\mathrm{db}=$ Derajad Bebas, KT $=$ Kuadrat Tengah, PJUT $=$ Persentase Jumlah Umbi Terserang, SUT $=$ Severitas Umbi Terserang, JLPI $=$ Jumlah Larva+Pupa+Imago, $* *=$ berpengaruh sangat nyata pada Uji $\mathrm{F}(\mathrm{p}<0,01)$, * = berpengaruh nyata pada $\mathrm{Uji} F(\mathrm{p}<0,05)$, tn $=$ berpengaruh tidak nyata pada Uji F $(p>0,05)$.

Tabel 2. Persentase jumlah umbi terserang dan severitas umbi terserang pada klon-klon ubi jalar yang terserang hama lanas.

\begin{tabular}{|c|c|c|c|c|c|c|}
\hline \multirow{3}{*}{ Klon } & \multicolumn{4}{|c|}{ Jumlah umbi terserang (\%) } & \multicolumn{2}{|c|}{ Severitas umbi teserang $(\%)$} \\
\hline & \multicolumn{4}{|c|}{ Lokasi produksi umbi } & \multicolumn{2}{|c|}{ Lokasi produksi umbi } \\
\hline & \multicolumn{2}{|c|}{ TTS } & \multicolumn{2}{|c|}{ Ende } & TTS & Ende \\
\hline $\mathrm{ON}-07$ & 65,93 & bcd & 77,10 & $\mathrm{c}$ & $14,89 \mathrm{~A}$ a & $55,72 \mathrm{~B} \quad \mathrm{~cd}$ \\
\hline ON-06 & 77,10 & $\mathrm{~cd}$ & 65,93 & $\mathrm{bc}$ & $23,06 \mathrm{~A}$ a & $19,82 \mathrm{~A} \mathrm{ab}$ \\
\hline ORM-02 & 77,10 & $\mathrm{~cd}$ & 59,43 & $a b c$ & $19,00 \mathrm{~A}$ a & $47,50 \mathrm{~B} \quad \mathrm{c}$ \\
\hline SEO-0 1 & 41,76 & $a b$ & 59,43 & $a b c$ & $5,04 \mathrm{~A}$ a & $36,56 \mathrm{~B} \mathrm{bc}$ \\
\hline NBN-01 & 24,08 & $\mathrm{a}$ & 30,58 & $\mathrm{a}$ & $3,83 \mathrm{~A}$ a & $5,17 \mathrm{~A} \mathrm{a}$ \\
\hline LB-01 & 48,25 & $a b c$ & 59,43 & $a b c$ & $12,83 \mathrm{~A}$ a & $25,67 \mathrm{~A} a b$ \\
\hline NPL-0 2 & 88,28 & $\mathrm{~d}$ & 77,68 & $\mathrm{c}$ & $66,16 \mathrm{~A} \mathrm{~b}$ & $67,89 \mathrm{~A} \mathrm{~d}$ \\
\hline EBS-01 & 48,25 & $\mathrm{abc}$ & 41,76 & $a b$ & $12,00 \mathrm{~A}$ a & $9,94 \mathrm{~A}$ a \\
\hline Kidal & 65,93 & bcd & 48,25 & $a b c$ & $14,28 \mathrm{~A}$ a & $17,00 \mathrm{~A} \mathrm{ab}$ \\
\hline P.Solossa & 65,93 & bcd & 65,93 & $\mathrm{~b}$ & $11,00 \mathrm{~A} \mathrm{a}$ & $51,38 \mathrm{~B} \mathrm{~cd}$ \\
\hline
\end{tabular}

Angka yang tertera pada kolom merupakan rerata dari tiga ulangan. Data hasil transformasi akar $(\mathrm{x}+0,05)$. Notasi huruf kecil menunjukkan perbandingan menurut kolom sedangkan huruf kapital menunjukkan perbandingan menurut baris. Angka-angka yang diikuti oleh huruf yang sama pada kolom atau baris yang sama, berbeda tidak nyata pada Uji DMRT ( $p>0,05)$.

menunjukkan bahwa lokasi produksi umbi diduga berpengaruh terhadap kualitas umbi sehingga mempengaruhi preferensi hama lanas terhadap umbi klon-klon tersebut. Pengaruh genotip dan lokasi produksi umbi ubi jalar terhadap jumlah luka pada permukaan umbi akibat serangan hama lanas telah dilaporkan sebelumnya oleh Mao et al. (2001).

Klasifikasi Tingkat Ketahanan. Data severitas umbi terserang diberi skor, kemudian digunakan untuk klasifikasi tingkat ketahanan klon-klon ubi jalar yang diuji. Skor ketahanan cukup bervariasi, berkisar antara 1,28 3,83 (Tabel 3). Baik pada lokasi produksi umbi TTS maupun Ende, klon lokal NBN-01 menunjukkan skor terendah, berturut-turut sebesar 1,28 dan 1,48 sedangkan skor tertinggi diperoleh pada klon lokal NPL-02, masingmasing sebesar 3,83 dan 3,69 untuk umbi asal TTS dan Ende. Hal ini mengindikasikan bahwa kedua klon tersebut secara konsisten menunjukkan karakter genetiknya sebagai klon yang paling tahan (NBN-01) dan yang paling peka (NPL-2) terhadap hama lanas pada dua lokasi produksi umbi.

Tabel 3 menunjukkan bahwa secara rata-rata untuk gabungan dua lokasi produksi umbi, klon-klon yang diuji bervariasi dalam hal tingkat ketahanannya terhadap hama lanas, terdiri dari "tahan" (T), "agak tahan" (AP), 
Tabel 3. Rata-rata skor ketahanan dan klasifikasi ting kat ketahanan klon-klon ubi jalar yang diuji.

\begin{tabular}{|c|c|c|c|c|c|c|}
\hline \multirow{3}{*}{ Klon } & \multicolumn{3}{|c|}{ Skor ketahanan } & \multicolumn{3}{|c|}{ Klasifikasi Ketahanan } \\
\hline & \multicolumn{2}{|c|}{ Lokasi produksi umbi } & \multirow{2}{*}{ Rata-rata } & \multicolumn{2}{|c|}{ Lokasi produksi umbi } & \multirow{2}{*}{ R ata-rata } \\
\hline & TTS & Ende & & TTS & Ende & \\
\hline $\mathrm{ON}-07$ & 2,10 & 3,12 & 2,61 & AT & AP & AT \\
\hline ON-06 & 2,26 & 1,96 & 2,11 & AT & AT & AT \\
\hline ORM-02 & 2,17 & 2,93 & 2,55 & AT & AP & AT \\
\hline SEO-01 & 1,32 & 2,18 & 1,75 & $\mathrm{~T}$ & AT & AT \\
\hline NBN-0 1 & 1,28 & 1,48 & 1,38 & $\mathrm{~T}$ & $\mathrm{~T}$ & $\mathrm{~T}$ \\
\hline LB-01 & 1,92 & $2,, 21$ & 2,07 & AT & AT & AT \\
\hline NPL-02 & 3,83 & 3,69 & 3,76 & $\mathrm{P}$ & $\mathrm{P}$ & $\mathrm{P}$ \\
\hline EBS-01 & 1,70 & 1,66 & 1,68 & AT & AT & AT \\
\hline KIDAL & 1,97 & 1,88 & 1,92 & AT & AT & AT \\
\hline P.Solossa & 1,93 & 2,49 & 2,21 & AT & AP & AT \\
\hline
\end{tabular}

Angka yang tertera pada kolom merupakan rerata dari tiga ulangan.

dan "peka" (P). Dari 10 klon yang diuji, hanya satu klon lokal yang "tahan" terhadap hama lanas, enam klon lokal dan dua varietas pembanding "agak tahan" dan satu klon lokal "peka" terhadap hama lanas. Rendahnya jumlah klon yang tahan terhadap hama lanas yang ditemukan dalam penelitian ini, telah pula dialami dalam penelitian terdahulu, misalnya Zuraida et al. (2005) hanya mendapatkan satu aksesi yang "tahan" dan 9 aksesi "agak tahan" dari 50 aksesi yang diuji. Sementara itu, Rais et al. (2004) berhasil mengidentifikasi 11 aksesi ubi jalar yang "tahan" terhadap hama lanas dari 70 aksesi yang dievaluasi. Perbedaan jumlah klon tahan yang teridentifikasi diduga dipengaruhi juga oleh metode dan kriteria evaluasi yang digunakan.

Data pada Tabel 3 juga menunjukkan bahwa tingkat ketahanan sebagian besar klon yang diuji konsisten antara lokasi produksi umbi TTS dan Ende, kecuali ON-07, SEO-01, ORM-02 dan P.Solossa. Adanya konsistensi ketahanan sebagian besar klon yang diuji mengindikasikan bahwa tingkat ketahanan klon-klon tersebut merupakan ekspresi karakter genetik yang dimiliki, dan merupakan sifat ketahanan sejati. Adanya inkonsistensi tingkat ketahanan pada empat klon lainnya menunjukkan adanya perbedaan ekspresi ketahanan klon-klon tersebut ketika ditanam di lokasi yang berbeda, yang dapat disebabkan oleh perbedaan jenis dan kandungan hara tanah maupun kondisi lingkungan penanaman, termasuk suhu, kelembaban, intensitas cahaya, dan ketinggian tempat. Sejalan dengan hasil ini, Mao et al. (2001) menemukan bahwa lokasi produksi umbi sedikit berpengaruh terhadap ekspresi ketahanan terhadap hama lanas, namun hasil akhirnya sangat ditentukan oleh jenis klon ubi jalar yang diuji.

Secara umum terdapat konsistensi antara tingkat ketahanan, baik pada umbi yang diproduksi di TTS maupun di Ende. Hal ini menunjukkan bahwa tingkat ketahanan pada klon-klon yang diuji mencermikan variasi potensi genetik, yang mengendalikan/mengontrol ketahanan klon-klon tersebut terhadap hama lanas. Cerminan ekspresi potensi genetik klon-klon ubi jalar tersebut didukung oleh data dalam penelitian ini; bahwa dua varietas pembanding yakni Kidal dan P. Solossa, masing-masing memberi reaksi "agak tahan" terhadap hama lanas, sesuai dengan deskripsi kedua varietas tersebut. Hal ini mengindikasikan bahwa ekspresi ketahanan klon-klon yang diuji benar-benar karena ketahanan sejati (genetic/true resistance) dan bukan karena lolos (escape) atau terhindar (avoidance) dari serangan hama lanas.

Ketahanan genetis terhadap hama lanas dapat diukur dari nilai heritabilitas karakter-karakter yang berhubungan dengan ketahanan. Semakin tinggi nilai heritabilitas (kisaran 0-1) berarti semakin besar pula pengaruh faktor genetis terhadap karakter tersebut sehingga berpeluang untuk diwariskan/dipertahankan dari generasi ke generasi. Publikasi hasil penelitian tentang heritabilitas ketahanan terhadap hama lanas sangat terbatas. Penelitan terdahulu oleh Sta.Cruz \& Chujoy (1994) menemukan bahwa heritabilitas dalam arti sempit untuk umbi rusak (berdasarkan berat dan jumlah) oleh hama lanas pada beberapa genotip ubi jalar berkisar antara 0,27 - 0,39 yang dianggap memiliki prospek untuk digunakan dalam program seleksi dan 
pemuliaan ubi jalar. Dari hasil penelitian ini, heritabilitas dalam arti luas untuk karakter severitas umbi terserang untuk masing-masing dan gabungan dua lokasi produksi umbi berkisar dari 0,48 - 0,90. Dengan demikian, klonklon yang dalam penelitian ini memiliki ketahanan yang baik terhadap lanas berpeluang untuk diseleksi dan dikembangkan menjadi varietas unggul tahan hama lanas di kemudian hari.

Jumlah Populasi Larva, Pupa dan Imago. Fase hama lanas yang paling merusak umbi adalah larva. Fase ini merusak dengan cara menggerek dan melubangi umbi kemudian masuk ke dalam dan makan daging umbi. Larva berkembang menjadi pupa dan selanjutnya menjadi imago. Dengan demikian, tingkat kerusakan umbi dapat diprediksi dari banyaknya jumlah larva, pupa dan imago yang terdapat dalam umbi. Hasil sidik ragam menunjukkan bahwa interaksi genotip dan lokasi produksi umbi berpengaruh sangat nyata $(\mathrm{P}<0,01)$ terhadap jumlah larva+pupa+imago (Tabel 1). Hal ini menunjukkan bahwa jumlah larva+pupa+imago pada klon-klon yang diuji dipengaruhi oleh hasil interaksi antara faktor genetik ubi jalar dan lokasi di mana umbi diproduksi. Jumlah larva+pupa+imago yang dapat hidup, makan dan berkembang biak pada umbi ubi jalar sangat dipengaruhi oleh jenis klon ubi jalar, dan jumlah larva+pupa+imago berubah seiring perubahan lokasi produksi umbi. Ratarata untuk dua lokasi produksi umbi (Tabel 4), populasi larva+pupa+imago terendah terdapat pada klon NBN01 (1,17 ekor/umbi) sedangkan populasi tertinggi pada klon NPL-02 (3,27 ekor/umbi), yang secara statistik berbeda dengan klon lainnya.

Mengingat bahwa kerusakan pada umbi bersifat kumulatif (kerusakan karena larva yang diamati saat penelitian tidak bisa dipisahkan dengan kerusakan karena larva yang telah berkembang menjadi pupa dan imago), maka data rata-rata jumlah larva+pupa+imago dapat dikorelasikan terhadap tingkat kerusakan umbi untuk melihat keeratan hubungan antara kedua peubah tersebut. Hasil analisis korelasi menunjukkan adanya hubungan yang kuat antara rata-rata jumlah larva+pupa+imago dan rata-rata severitas umbi terserang dengan koefisien korelasi, $r=0,87$. Hal ini mengindikasikan bahwa severitas umbi terserang semakin meningkat seiring dengan meningkatnya jumlah populasi jumlah larva+pupa+imago dalam umbi. Semakin banyak larva dan pupa serta imago yang terdapat pada umbi, semakin banyak pula makanan yang dibutuhkan, dan semuanya ini diperoleh dengan cara merusak umbi.

\section{Hubungan Karakteristik Umbi dan Tingkat Ketahanan terhadap Hama Lanas. Tingkat ketahanan} terhadap hama lanas tidak secara jelas dapat dikaitkan/ dijelaskan oleh karakteristik morfologis umbi ubi jalar yang diuji (Tabel 5). Klon yang "tahan" (NBN-01) memiliki warna daging umbi 'putih', sebagaimana halnya lima klon yang "agak tahan" (SEO-01, EBS-01, ON06, ON-07, ORM-02), sedangkan dua varietas pembanding "agak tahan" (Kidal, P. Solossa) dan klon "peka" (NPL-02) memiliki warna daging umbi kuning.

Tabel 4. Rata-rata jumlah larva+ pupa+imago per umbi pada klon-klon ubi jalar yang diuji.

\begin{tabular}{|c|c|c|c|}
\hline \multirow{2}{*}{ Klon } & \multicolumn{2}{|c|}{ Lokasi produksi umbi } & \multirow{2}{*}{ Rata-rata } \\
\hline & TTS & Ende & \\
\hline $\mathrm{ON}-07$ & 2,73 A cde & 2,91 A cd & $2,82 \mathrm{cde}$ \\
\hline ON-06 & $2,33 \mathrm{~A} \mathrm{bc}$ & 2,15 A bc & $2,22 \mathrm{bcd}$ \\
\hline OR M-02 & $3,57 \mathrm{~B} \mathrm{e}$ & $2,55 \mathrm{~A} \mathrm{bcd}$ & $3,06 \mathrm{de}$ \\
\hline SEO-01 & $1,77 \mathrm{~A} \mathrm{ab}$ & $1,87 \mathrm{~A} \mathrm{ab}$ & $1,82 \mathrm{ab}$ \\
\hline NBN-0 1 & $1,21 \mathrm{~A} \mathrm{a}$ & $1,14 \mathrm{~A} \mathrm{a}$ & $1,17 \mathrm{a}$ \\
\hline LB-01 & 2,82 B cde & $1,99 \mathrm{~A}$ ab & 2,40 bcde \\
\hline NPL-02 & 3,32 A de & $3,22 \mathrm{~A} \mathrm{~d}$ & $3,27 \mathrm{e}$ \\
\hline EBS-01 & $2,31 \mathrm{~A} \mathrm{bc}$ & $1,77 \mathrm{~A}$ ab & $2,04 \mathrm{bc}$ \\
\hline KID AL & 2,53 A bcd & $1,89 \mathrm{~A} \mathrm{ab}$ & $2,21 \mathrm{bcd}$ \\
\hline P.Solossa & $2,31 \mathrm{~A} \mathrm{bc}$ & 2,43 A bcd & $2,37 \mathrm{bcd}$ \\
\hline Rata-rata & $2,50 \mathrm{~A}$ & $2,19 \mathrm{~A}$ & \\
\hline
\end{tabular}

Angka yang tertera pada kolom merupakan rerata dari tiga ulangan. Data hasil transformasi Arcsin. Notasi huruf kecil menunjukkan perband ingan menurut kolom sedangkan huruf kapital menunjukkan perb an dingan menurut $b$ aris. Angka-angka yang diiukuti oleh huruf yang sama pada kolom atau bar is yang sama, berbeda tidak nyata pada Uji DMRT $(P>0,05)$. 
Tabel 5. Ting kat ketahanan terhadap hama lanas dan karakteristik morfologis umbi klon-klon ubi jalar yan g diuji.

\begin{tabular}{lccccc}
\hline \multicolumn{1}{c}{ Klon } & $\begin{array}{c}\text { Skor } \\
\text { Ketahanan }\end{array}$ & $\begin{array}{c}\text { Warna daging } \\
\text { umbi }\end{array}$ & $\begin{array}{c}\text { Warna kulit } \\
\text { umbi }\end{array}$ & $\begin{array}{c}\text { Produksi } \\
\text { getah }\end{array}$ & $\begin{array}{c}\text { Tebal ku lit } \\
\text { umbi }\end{array}$ \\
\hline NBN-01 & $1,35(\mathrm{~T})$ & Putih & Merah & Sedikit & $4 \mathrm{~mm}$ \\
SEO-01 & 1,69 (AT) & Putih & Merah & Sedikit & $4 \mathrm{~mm}$ \\
EBS-01 & $1,72($ AT) & Putih & Merah & Sedikit & $2 \mathrm{~mm}$ \\
LB-01 & $1,85($ AT) & Oranye & Krem & Agak banyak & $4 \mathrm{~mm}$ \\
Kidal & $1,85($ AT) & Kuning & Merah & Banyak & $4 \mathrm{~mm}$ \\
P.Solossa & $2,03($ AT) & Kuning & Kuning & Banyak & $4 \mathrm{~mm}$ \\
ON-06 & $2,05($ AT) & Putih & Merah & Sedikit & $4 \mathrm{~mm}$ \\
ORM-02 & $2,25($ AT) & Putih & Merah & Sedikit & $3 \mathrm{~mm}$ \\
ON-07 & $2,41($ AT) & Putih & Merah & Sedikit & $4 \mathrm{~mm}$ \\
NPL-02 & $4,40(P)$ & Kuning & Kuning & Sedikit & $3 \mathrm{~mm}$ \\
\hline
\end{tabular}

Urutan klon disusun sesuai dengan skor ketahanan (dimulai dari yang paling tahan). $\mathrm{T}=$ tahan, $\mathrm{AT}=$ agak tahan, $\mathrm{P}=$ peka.

Dalam hal warna kulit umbi, klon yang "tahan" berwarna merah, sebagaimana halnya dengan enam klon yang "agak tahan" (SEO-01, EBS-01, Kidal, ON-06, ON-07, ORM-02), sedangkan varietas pembanding "agak tahan" (P. Solossa) memiliki warna warna umbi kuning, sama dengan klon "peka" (NPL-02). Dengan demikian, warna daging umbi dan warna kulit umbi tidak terkait erat dengan tingkat ketahanan.

Dalam hal produksi getah, klon "tahan" (NBN01) memproduksi getah dalam jumlah "sedikit" seperti halnya lima klon "agak tahan" (SEO-01, EBS-01, ON06, ON-07 ORM-02), dan klon "peka" (NPL-02). Hal yang sama terjadi pada ketebalan umbi di mana hampir semua klon yang diuji memiliki ketebalan yang sama (4 $\mathrm{mm})$ kecuali klon "agak tahan" EBS-02 (2 mm) dan klon "peka" NPL-02 (3 mm). Uraian di atas menunjukkan bahwa karakter morfologis umbi klon/ varietas ubi jalar yang diuji tidak secara tegas dapat dikaitkan dengan tingkat ketahanan terhadap hama lanas. Dengan demikian, diduga bahwa ada faktor lain selain karakter morfologis umbi yang berpengaruh terhadap tingkat ketahanan terhadap hama lanas. Faktor-faktor lain tersebut tidak diamati dalam penelitian ini.

\section{SIMPULAN}

Berdasarkan hasil penelitian dan pembahasan, maka dapat disimpulkan bahwa tingkat ketahanan klonklon ubi jalar yang diuji terhadap hama lanas dikelompokkan menjadi tiga kategori yakni: "tahan", "agak tahan", dan "peka". Terdapat satu klon lokal (NBN-01) yang "tahan", enam klon lokal (SEO-01, EBS01, LB-01, ON-06, ON-07, ORM-02) dan dua varietas pembanding (Kidal, P.Solossa) yang "agak tahan", dan satu klon lokal (NPL-02) yang "peka" terhadap hama lanas. Interaksi genotipe x lokasi produksi umbi berpengaruh sangat nyata terhadap peubah "severitas umbi terserang" dan "populasi larva+pupa+imago". Karakteristik morfologis umbi seperti warna daging umbi, warna kulit umbi, produksi getah, dan ketebalan kulit umbi tidak terkait erat dengan tingkat ketahanan terhadap hama lanas.

\section{SANWACANA}

Ucapan terimakasih disampaikan kepada pihak Direktorat Jenderal Pendidikan Tinggi, Kementerian Pendidikan Nasional, atas dukungan dana untuk pelaksanaan penelitian ini melalui skim Hibah Penelitian Strategis Nasional Dikti Tahun Anggaran 2010.

\section{DAFTAR PUSTAKA}

Amalin DM. 1994. Arthropod Pest Damage Evaluation In Relation To Varietal Resistance Evaluation In Sweetpotato. In: Rasco, JET \& Amante VDR. Eds. Sweetpotato Variety Evaluation. SAPPRAD 1:56-59.

Cahyono B \& Juanda D. 2000. Ubi Jalar. Budidaya dan Analisis Usaha Tani. Penerbit Kanisius, Yogyakarta.

Jansson RK, Bryan HH \& Sorensen KA. 1987. Withinvine distribution and damage of sweetpotato weevil, Cylas formicarius elegantulus (Coleoptera; Curculionidae) on four cultivars of 
sweet potato in Suthern Florida. Florida Entomologist 70(4):523-526.

Mao L, Jett LE, Story RN, Hammond AM \& Labonte DR. 2001. Effect of sweet potato genotype, storage time, and production site on feeding and oviposition behaviour of the sweetpotato weevil, Cylas formicarius (Coleoptera: Apoinidae). Florida Entomologist 84(2):259-264.

Mao L, Jett LE, Story RN, Hammond AM, Peterson JK \& Labonte DR. 2004. Influence of drought stress on sweetpotato resistance to sweetpotato weevil, Cylas formicarius (Coleoptera: Apoinidae) and storage root chemistry. Florida Entomologist 87(3):261-267.

Mau YS, Ndiwa ASS \& Arsa IGBA. 2008. Perbaikan Mutu Genetik Ubi Jalar Lokal Asal Timor Barat Melalui Seleksi Daya Hasil Dan Ketahanan Terhadap Cekaman Kekeringan. Laporan Penelitian Hibah Bersaing. Lembaga Penelitian, Universitas Nusa Cendana. Kupang.

Mau YS, Ndiwa ASS, Arsa IGBA \& Oematan SS. 2009. Uji Daya Hasil Beberapa Klon Ubi Jalar Lokal Asal Timor Barat dan Introduksi pada beberapa Daerah Sentra Produksi di NTT. Laporan Penelitian Hibah Strategis Nasional. Lembaga Penelitian, Universitas Nusa Cendana, Kupang.

Ndiwa ASS, Arsa IGBA, Kasim M, Adutae ASJ \& Abidin Z. 2007. Inventarisasi dan Identifikasi Klon-Klon Ubi Jalar Lokal Asal NTT di Kabupaten TTS dan TTU. Laporan Penelitian. Pusat Penelitian dan Pengembangan UmbiUmbian dan Kacang-Kacangan Universitas Nusa Cendana, Kupang.
Rais SA, Silitonga TS, Budiarti SG, Zuraida N \& Sudjadi M. 2004. Evaluasi Ketahanan Plasma Nutfah Tanaman Pangan terhadap Cekaman Beberapa Faktor Biotik (Hama dan Penyakit). Risalah Seminar Hasil Penelitian Rintisan dan Bioteknologi Tanaman, Balai Besar-Biogen Bogor: 163-174.

Rukmana R. 1997. Ubi Jalar. Ubi Jalar dan Pascapanen. Penerbit Kanisius, Yogyakarta.

Sta. Cruz, MTLG \& Chujoy E. 1994. Heritability estimates of some root characters in sweetpotatoes. Phillipine Journal of Crop Science 19(1):27-32.

Supriyatin \& Rahayuningsih A. 1994. Evaluasi ketahanan klon ubi jalar terhadap hama boleng (Cylas formicarius F.). Edisi Khusus Balittan Malang 3:211-215.

Zuraida N, Silitonga TS, Suyono, Minantyorini \& Koswanudin D. 2004. Evaluasi ketahanan beberapa plasma nutfah tanaman terhadap hama (Wereng Coklat pada padi dan Hama Lanas pada Ubi Jalar). Risalah Seminar Hasil Penelitian Rintisan dan Bioteknologi Tanaman, Balai Besar-Biogen Bogor:42-48.

Zuraida N, Minantyorini \& Koswanudin D. 2005. Penyaringan ketahanan plasma nutfah ubi jalar terhadap hama lanas. Buletin Plasma Nutfah 11(1):11-15. 